\title{
PENDEKATAN KESEJAHTERAAN SEBAGAI STRATEGI PENGUATAN NASIONALISME MASYARAKAT DI KAWASAN PERBATASAN
}

\author{
Makarius Erwin Bria, Suharno \\ Program Pascasarjana Pendidikan Pancasila dan Kewarganegaraan \\ Universitas Negeri Yogyakarta \\ Jl. Colombo No.1, Sleman, Daerah Istimewa Yogyakarta \\ erwinbria213@gmail.com
}

\begin{abstract}
This article aims to discuss the border situation in East Kobalima District, East Nusa Tenggara, which is far from the reach of the government. The low development potential in the border region triggers problems that affect the sense of nationalism. The method used is a qualitative approach type case study. This article discusses the welfare approach as a strategy implemented by the Border Management Agency of the East Nusa Tenggara Province to strengthen the nationalism of the border communities. The welfare approach implemented includes 1) infrastructure development and improvement; and 2) improving community welfare. Through a welfare approach, the community feels the presence of the state so that it can strengthen the spirit of nationalism and greater citizen loyalty to maintain the existence of Indonesianism in the border region.
\end{abstract}

Keywords: border society, nationalism, welfare approach

\begin{abstract}
Abstrak: Artikelini bertujuan untuk membahas keadaan perbatasan di Kecamatan Kobalima Timur, Nusa Tenggar Timur, yang tergolong jauh dari jangkauan pemerintah. Rendahnya pengembangan potensi di wilayah perbatasan tersebut memicu terjadinya permasalahan yang berpengaruh pada rasa nasionalisme masyarakat. Metode yang digunakan adalah pendekatan kualitatif jenis case study. Artikel ini membahas tentang pendekatan kesejahteraan sebagai strategi yang dilaksanakan oleh Badan Pengelola Perbatasan Provinsi Nusa Tenggara Timur untuk menguatkan nasionalisme masyarakat perbatasan. Pendekatan kesejahteraan yang dilaksanakn meliputi 1) pembangunan dan peningkatan infrastruktur; dan 2) peningkatan kesejahteraan masyarakat. Melalui pendekatan kesejahteraan, masyarakat merasakan hadirnya negara sehingga mampu menguatkan semangat nasionalisme dan loyalitas warga negara semakin besar untuk mempertahankann eksistensi ke-Indonesia-an di kawasan perbatasan negara.
\end{abstract}

Kata kunci: masyarakat perbatasan, nasionalisme, pendekatan kesejahteraan

Negara Indonesia merupakan negara yang beraneka ragam suku, agama dan ras, wilayah yang sangat luas terdiri atas ribuan pulau, serta memiliki wilayah yang berbatasan langsung dengan negara lain, baik itu batas darat, laut, maupun udara. Keanekaragaman serta letak wilayah yang berbatasan langsung dengan beberapa negara tetangga, Negara Indonesia kini dihadapkan pada sebuah tantangan besar yakni bagaimana mempertahankan semangat nasionalisme bangsa dan menjaga identitas nasional. Bangsa Indonesia harus tetap memiliki daya pengikat yang dapat mempererat persatuan dan kesatuan bangsa yakni nasionalisme dan kebanggaan menjaga identitas bangsa untuk mempertahankan kedaulatan Negara Kesatuan Republik Indonesia.

Bagi bangsa Indonesia, nasionalisme merupakan jiwa kebangsaan yang mutlak harus ada karena keragaman bangsa Indonesia, terdiri dari berbagai suku bangsa, agama, budaya, dan bahasa. Kebulatan tekad untuk mewujudkan nasionalisme bangsa Indonesia tercermin dalam "Sumpah Pemuda" tanggal 28 Oktober 1928 (Bakry, 2014: 87). Nasionalisme di Indonesia sesungguhnya tidak terlepas dari kenyataan bahwa masyarakat Indonesia yang plural dan 
multikultural dengan beragam budaya. Lan \& Manan (2011:4) mengemukakan bahwa ibaratnya mata uang dengan dua sisi berbeda tetapi tidak dapat dipisahkan, nasionalisme Indonesia dapat dilihat sebagai suatu "ikatan budaya" yang menyatukan dan mengikat masyarakat plural Indonesia menjadi suatu bangsa. Adanya kemiskinan, korupsi, melemahnya ketahanan budaya, konflik yang mengatasnamakan agama, merupakan suatu tantangan baik secara langsung maupun tidak langsung dapat mempengaruhi kadar nasionalisme bangsa Indonesia.

Masyarakat di kawasan perbatasan memiliki karakteristik yang berbeda serta khas jika dibandingkan dengan masyarakat yang tidak berasal dan tinggal di kawasan perbatasan. Ditambah lagi dengan adanya kemudahan mengakses informasi melalui media masa dan interaksi langsung dengan penduduk di negara tetangga, serta kurangnya pengelolaan kawasan perbatasan menimbulkan kesenjangan di kawasan perbatasan. Pamungkas (2015: 152) membenarkan asumsi tersebut melalui hasil penelitiannya yang menunjukkan adanya kesenjangan antara pandangan sosial ekonomi dan keterikatan dalam entitas politik. Adanya kecenderungan masyarakat perbatasan di daerah Karimun, Kepulauan Riau, yang lebih sering berobat ke kota-kota di Malaysia dari pada di Indonesia. Aktivitas ini dikarenakan pelayanan dari negara Malaysia dinilai lebih baik pelayanan kesehatannya jika dibandingkan dengan pelayanan kesehatan di Indonesia.

Permasalahan lain yang terjadi di kawasan perbatasan (Mansyah, 2017:19) antara lain: pertama, kondisi perbatasan yang terisolir dan tertinggal dibandingkan dengan daerah lain disebabkan kurangnya perhatian dari pemerintah sehingga tidak ada wujud pembangunan yang dilaksanakan selama ini. Kedua, masyarakat Malaysia di perbatasan tingkat pereko-nomiannya relatif lebih baik dari masyarakat Indonesia, hal ini akan berpengaruh terhadap nasionalisme masyarakat di perbatasan. Ketiga, infrastruktur seperti jalan, rumah sakit, pasar dan sekolah terbatas sehingga kehidupan sosial budaya masyarakat kualitasnya sangat rendah. Keempat, rendahnya sumber daya manusia di perbatasan menyebabkan daya saing dan kopetensi masyarakat perbatasan selalu kalah dalam persaingan.

Beberapa permasalahan yang dikemukakan tersebut tidak berbeda jauh dengan kondisi yang dialami oleh masyarakat perbatasan di Kecamatan Kobalima Timur. Kecamatan Kobalima Timur merupakan salah satu lokasi prioritas dari 5 Lokasi Prioritas (lokpri) di Kabupaten Malaka, Provinsi Nusa Tenggara Timur.Kecamatan Kobalima Timur memiliki wilayah yang berbatasan darat dengan Negara Democratic Timor Leste (RDTL). Keadaan wilayah ini tergolong sebagai daerah tertinggal karena masih jauh dari jangkauan pemerintah sehingga pembangunan serta pengembangan potensi yang ada di wilayah ini masih sangat minim jika dibandingkan dengan daerah lain. Hal ini juga menjadi pemicu terjadinya penyelundupan barang secara ilegal untuk dijual ke negara Timor Leste sebagai penopang keadaan ekonomi keluarga dari hasil penjualan tersebut. Kurangnya perhatian pemerintah pada masyarakat di kawasan perbatasan mampu menimbulkan dampak yang berpengaruh terhadap semangat nasionalisme masyarakat di kawasan perbatasan itu sendiri.

Permasalahan tersebut bukan semata-mata hanya persoalan intern yang dihadapi oleh masyarakat di Kecamatan Kobalima Timur. Lebih dari itu, permasalahan tersebut beruhubungan erat dengan eksistensi dan kedaulatan Negara kesatuan Republik Indonesia di kawasan perbatasan. Oleh karena itu, pemerintah sebagai elemen pengelola perlu meningkatkan pengembangan kawasan perbatasan dengan menggunakan pendekatan kesejahteraan agar dapat menopang kehidupan ekonomi masyarakat dan memiliki dampak positif terhadap nasionalisme masyarakat di Kecamatan Kobalima Timur.

\section{METODE}

Metode yang digunakan dalam kajian ini adalahdeskriptif kualitatif dengan jenis studi kasus (casestudy). Studi kasus merupakan suatu studi tentang kasus atau rangkaian kasus tertentu, menggambarkan atau menjelaskan suatu kejadian yang terjadi. Suatu studi kasus bisa digunakan pada penelitian kualitatif atau penelitian kuantitatif(bisa juga keduanya) dengan perolehan data dari lapangan(Yin, 2011: 307). Penggunaan studi kasus dapat mengekplorasi secara mendalam terhadap suatu program, proses, kejadian, aktivitas, terhadap satu orang atau lebih (Sugiyono, 2016: 15).

Kajian ini bertujuan untuk mendeskripsikan pendekatan kesejahteraan yang dilaksanakan olehBadan Pengelola Perbatasan Propinsi Nusa 
Tenggara Timur untuk menguatkan nasionalisme masyarakat yang berada di kawasan perbatasan. Kawasan perbatasan yang dimaksud adalah wilayah perbatasanantara Indonesia dan Republik Demokratik Timor Leste (RDTL), khusunya di Lokasi Prioritas (Lokpri) Kecamatan Kobalima Timur Kabupaten Malaka.

Pengumpulan data dilakukan dengan menggunakan teknik observasi, dokumentasi, dan wawancara. Temuan yang diperoleh dari hasil wawancara menjadi data primer. Sedangkan data sekunder berupa temuan yang diperoleh dari hasil observasi dan studi dokumentasi seperti laporan, catatan, majalah, media massa, dokumen badan pengelola perbatasan (rencana aksi dan rencana induk). Data yang telah dikumpulkan kemudian direduksi dan selanjutnya disajikan dalam bentuk teks naratif sehingga mudah untuk dimengerti dan ditarik kesimpulan hasil penelitian. Penentuan subjek menggunakan teknik snowball sampling, artinya data dikumpulkan dari informan melalui wawancara mendalam sampai data yang diperoleh mengalami titik jenuh (tidak ada informasi baru lagi).

\section{HASIL DAN PEMBAHASAN}

\section{Pembangunan dan Peningkatan Infrastruktur di Kawasan Perbatasan}

Daerah perbatasan umumnya merupakan daerah yang jauh dari pusat pemerintahan. Kesenjangan sosial politik serta ekonomi sering muncul sebagai akibat perbedaan perlakuan pemerintah pusat. Garis batas wilayah Indonesia yang panjang dan luas perlu diperhatikan dengan baik untuk mampu mempertahankan nasionalisme dan integritas serta kedaulatan negara. Dalam menjaga dan mengamankan wilayah Indonesia, khususnya di kawasan perbatasan, tidak hanya mengandalkan kekuatan Tentara Nasional Indonesia (TNI). Pengamanan kawasan perbatasan memerlukan peran yang besar dari masyarakat di kawasan perbatasan dalam melaksanakan hak dan kewajiban bela negara (sesuai dengan pasal 30 UUD 1945) secara efektif dan efisien. Keadaan geografis Indonesia yang berbatasan darat dengan negara tetangga maupun berbatasan laut, berpotensi menimbulkan konflik perbatasan. oleh karena itu, perlu ada bentuk cegah tangkal dini dalam pengawasan perbatasan agar tidak terjadi pelanggaran wilayah Republik Indonesia.
Di sisi lain, apabila dilihat pada keadaan dan kondisi saat ini, Indonesia kini mengalami berbagai masalah mulai dari kekerasan, isu SARA, bahkan pelanggaran Hak Asasi Manusia (HAM). Masalah-masalah tersebut tentunya mampu menjadi faktor pendorong lunturnya nilai-nilai nasionalisme. Lebih dari itu, Indonesia dikenal dengan negara kepulauan dan tersebar dari Sabang sampai Merauke, serta memiliki wilayah yang berbatasan langsung dengan negara lain, baik batas darat maupun batas laut, tentunya diperlukan campur tangan pemerintah agar dapat memperhatikan dan mengelolanya dengan baik.

Dihadapkan pada kondisi ini maka dibutuhkan campur tangan pemerintah setempat untuk membangun kawasan perbatasan dengan pendekatan kesejahteraan (prosperity), keamanan (security), dan lingkungan (environment) secara serasi (Muta'ali, et al., 2014: 33). Adanya campur tangan dari pihak pemerintah dalam pengelolaan wilayah negara secara menyeluruh menjadi satu faktor penguat nasionalisme masyarakat. Merujuk pada nasionalisme masyarakat perbatasan, nasionalisme masyarakat perbatasan berkaitan dengan spirit, semangat orang-orang perbatasan untuk menjaga dan mengembangkan kawasan perbatasan itu sendiri dan juga untuk mengembangkan kepribadian mereka sebagai orang-orang yang tinggal di kawasan perbatasan antara dua negara yang berbeda budaya, berbeda pendekatan, berbeda pembangunan dan lain-lain.

Kecamatan Kobalima Timur merupakan salah satu lokasi prioritas di Kabupaten Malaka Provinsi Nusa Tenggara Timur. Wilayah Kecamatan Kobalima Timur berbatasan darat dengan Negara Republik Demokratik Timor Leste (RDTL). Negara Republik Demokratik Timor Leste adalah adalah salah satu negara tetangga yang tergolong baru dan berbatasan darat dengan Negara Indonesia. Setelah pengunduran diri Soeharto sebagai presiden Indonesia dan dibawah tekanan internasional, pada awal tahun 1999, Presiden B. J. Habibie, mengumumkan bahwa Provinsi Timor Timur (sekarang Timor Leste) diperbolehkan untuk melakukan jajak pendapat untuk menentukan apakah masih ingin bergabung dengan Negara Kesatuan Republik Indonesia (NKRI) atau memilih untuk berpisah dan menjadi negara sendiri. Akhirnya, pada tanggal 30 Agustus 1999, 78,5\% pemilih yang terdaftar memilih untuk meninggalkan Indonesia, dengan kata lain berpisah dari Indonesia dan terbentuk menjadi negara sendiri (Kingsbury, 2003: 6). 
Perbatasan merupakan konsep geografisspasial. Perbatasan baru menjadi konsep sosial ketika kita berbicara tentang masyarakat yang menghuni atau melintasi daerah perbatasan. Suatu perbatasan seringkali didefinisikan sebagai garis imajiner diatas permukaan bumi, yang memisahkan wilayah satu negara dari negara lain. Sejauh perbatasan itu secara tegas diakui dengan traktat atau diakui secara umum tanpa pernyataan yang tegas, maka perbatasan merupakan bagian dari suatu hak negara terhadap wilayahnya. Pada dasarnya batas-batas kawasan perbatasan dapat diklasifikasikan dalam dua pendekatan; pertama, pendekatan yang bersifat fisik, artinya batas-batas tersebut dapat berupa batas alam dan batas buatan. Kedua, yaitu pendekatan yang bersifat geometrik, dimana batas-batas tersebut membagi kawasan perbatasan ke dalam batas-batas linier maupun nonlinier (Arifin, 2014:53).

Belum maksimalnya pengembangan dan pemanfaatan potensi kawasan perbatasan serta kurangnya ketersediaan sarana dan prasarana di kawasan perbatasan, merupakan permasalahan umum yang dijumpai di kawasan perbatasan wilayah negara Indonesia. Oleh karena itu, Badan Pengelola Perbatasan Provinsi Nusa Tenggara Timur tengah mengupayakan pengembangan kawasan perbatasan yang ada di wilayah Provinsi Nusa Tenggara Timur. Peningkatan infrastrukur di kawasan perbatasan di wilayah perbatasan yang ada di Propinsi Nusa Tenggara merupakan langkah pertama yang di lakukan. Peningkatan infrastruktur tersebut sejalan dengan visi dan misi Badan Nasional Badan Pengelola Perbatasan. Pelaksanaan peningkatan infrastruktur tentunya dapat mengurangi tingkat kemiskinan masyarakat yang ada di kawasan perbatasan. Lebih dari itu, peningkatan infrastruktur di kawasan perbatasan merupakan bentuk nyata yang mengindikasikan bahwa negara hadir dan memperhatikan masyarakat perbatasan. Dalam menjalankan fungsi koordinasi, pemerintah pusat dan pemerintah daerah propinsi dan kabupaten melakukan koordinasi dalam mengembangkan perbatasan yang ada di wilayah Nusa Tenggara Timur termasuk Lokasi Prioritas Kecamatan Kobalima Timur.

Peningkatan infrastrukur di wilayah Kobalima Timur meliputi pembangunan Pos Lintas Batas Negara Terpadu (PLBN) di Motamasin sebagai exit entry point antara Indonesia dan Republik Demokratik Timor Leste (RDTL).
Pembangunan Pos Lintas Batas Negara Terpadu Motamasin sesuai dengan Peraturan Kepala Badan Nasional Pengelola Perbatasan Nomor 8 Tahun 2015 tentang Master Plan Pos Lintas Batas Negara Terpadu Motamasin Kabupaten Malaka Provinsi Nusa Tenggara Timur. Sarana dan prasana yang dibangun meliputi 1) Banguna Utama PLBN; 2) Bangunan Pemeriksaan terpadu (Bea Cukai dan Karantina) kedatangan mobil pribadi, bus, dan barang; 3) Bangunan Klinik; 4) Bangunan car was (disinfection); 5) Bangunan jembatan timbang; 6) Bangunan pemindai truck; 7) Bangunan sita barang ringan dan berat; 8) Bangunan pemeriksa imigrasi keberangkatan dan kedatangan; 8) Ruang serba guna; dan beberapa gedung penunjang lainnya. Bangunan-bangunan tersebut dibangun dalam zona inti dan zona sub inti demi menunjang kelancaran proses pemeriksaan keluar masuk di pintu perbatasan negara. Selain itu, dengan adanya PLBN Terpadu Motamasin yang terkesan megah tersebut menjadi satu kebanggan tersendiri bagi masyarakat di sekitar PLBN. Jika dibandingkan, PLBN Motamasin terkesan lebih megah dari Pos Lintas Batas milik Negara Republik Demokratik Timor Leste.

Provinsi Nusa Tenggara Timur, terkhusus di wilayah Timor Barat terdapat 3 kecamatan yang tergolong sebagai kecamatan exit entry point yakni, PLBN Motaain di Kecamatan Tasifeto Timur, PLBN Motamasin di Kecamatan Kobalima Timur, dan PLBN Wini di Kecamatan Insana Utara. Ketiga Pos Lintas Batas Negara (PLBN) tersebut merupakan pintu masuk-keluar ke Negara Timor Leste.

Selain pembangunan PLBN Terpadu, ada peningkatan jalan sebagai akses masyarakat sehingga memudahkan masyarakat dalam melakukan aktivitasnya. Peningkatan jalan sepanjang perbatasan yang dinamakan "Sabuk Merah Perbatasan" merupakan bagian dari proyek Kementerian Pekerjaan Umum dan Perumahan Rakyat melalui Direktorat Jenderal Bina marga. Keberadaan jalan "sabuk merah perbatasan" ini merupakan perwujudan komitmen Nawacita Presiden Joko Widodo dan Wakil Presiden Yusuf Kalla. Ruas jalan Sabuk Merah Perbatasan sepanjang garis batas negara tersebut menghubungkan Pos Lintas Batas Negara di Motaain, Kabupaten Belu dan Pos Lintas Negara di Motamasin, Kabupaten Malaka. Pembangunan ruas jalan sepanjang 176,1 kilometer ini bertujuan 
untuk melancarkan akses untuk menunjang ekonomi masyarakat.

Peningkatan infrastruktur bagi masyarakat di Kecamatan Kobalima Timur mampu meningkatkan nasionalisme masyarakat. Pernyataan ini senada dengan Saiman (2017: 154) yang menegaskan bahwa kepentingan pemerintah dalam meningkatkan infrastruktur di perbatasan bertujuan untuk menguatkan nasionalisme masyarakat perbatasan. Kawasan perbatasan merupakan beranda depan NKRI, maka harus dibangun guna meningkatkan nasionalisme dan kesejahteraan serta kedaulatan NKRI.

Di sisi lain, peningkatan infrastruktur di Kecamatan Kobalima Timur juga mampu menopang kesejahteraan ekonomi masyarakat sehingga mampu mengurangi aktivitas ilegal dari masyarakat. Aktivitas ilegal yang dilakukan berupa penyelundupan Bahan bakar Minyak (BBM), bahan pokok, kendaraan bermotor, alat-alat elektronik, dan hewan ternak. Kenyataan tersebut dibenarkan oleh Wuryandari, et al., (2009: 19) bahwa barang yang sering diselundupkan adalah BBM, bahan pokok, dan sapi. Oleh karena itu, dengan adanya peningkatan infrastruktur tersebut, memiliki pengaruh signifikan sebagai upaya untuk mengatasi tindakan-tindakan ilegal tersebut.

Selaras dengan pernyataan Mansyah (2017: 37) menyatakan pemerintah perlu merealisasikan pembangunan infrastruktur jalan dan sarana umum lainnya agar dapat membuka dan menjangkau daerah terisolir serta memberikan kemudahan dalam memenuhi kebutuhan hidup guna meningkatkan kesejahteraan bagi masyarakat di kawasan perbatasan. Untuk itu, Moeldoko (2014, 267) mengemukakan bahwa pemerintah harus mampu menyediakan berbagai infrastrukutur dan fasilitas yang setara agar tidak melunturkan semangat kebangsaan masyarakat Indonesia di kawasan perbatasan.

Peningkatan infrastruktur merupakan faktor penting dalam mengelola perbatasan. Dengan adanya infrastruktur yang memadai, memudahkan akses masyarakat di kawasan perbatasan sehingga wilayah perbatasan ke depannya menjadi beranda depan yang mempunyai daya saing dan menjadi nilai tambah demi mewujudkan negara yang maju. Peningkatan infrastruktur juga memberikan dampak yang signifikan terhadap kemajuan dan kesejahteraan serta nasionalisme masyarakat di kawasan perbatasan. Pembangunan perbatasan dan nasionalisme merupakan dua unsur yang berkaitan erat. Semakin besar pembangunan yang dilakukan di kawasan perbatasan, semakin besar pula rasa kebanggan yang dimiliki oleh masyarakat perbatasan. Dengan demikian, pembangunan merupakan simbol kepedulian dan kehadiran negara di kawasan perbatasan yang dapat meningkatkan rasa nasionalisme masyarakat.

\section{Peningkatan Kesejateraan Masyarakat Perbatasan}

Kehidupan masyarakat yang sejahtera merupakan kondisi kondisi ideal dan menjadi dambaan setiap masyarakat. Secara umum, gambaran tentang wilayah perbatasan selalu berkaitan tentang daerah terluar, terdepan, dan terpencil. Merujuk pada pernyataan tersebut, maka dibutuhkan upaya pengelolaan perbatasan sehingga mampu mewujudkan kawasan perbatasan sebagai beranda depan NKRI yang berdaya saing dan sejahtera. Untuk mencapai hal tersebut, maka peningkatan kesejahteraan masyarakat di kawasan perbatasan merupakan unsur penting yang harus ditangani. Koordinasi dalam mengelola kawasan perbatasan harus lebih ditingkatkan untuk mewujudkan tujuan pembangunan dan kesejahteraan yang merata dan adil.

Kawasan perbatasan merupakan wilayah negara yang harus mendapatkan perhatian penuh dari pemerintah. Pemerintah dalam hal ini, tidak hanya terbatas pada pemerintah daerah tetapi merupakan tanggung jawab penuh dari pemerintah pusat. Salah satu bentuk perhatian pemerintah pusat kepada masyarakat di Kecamatan Kobalima Timur berupa pelaksanaan Program Kampung Sejahtera (bedah kampung). Program Kampung Sejahtera merupakan program yang pelaksananya terdiri dari gabungan 6 (enam) orang isteri menteri Kabinet Kerja. Program Kampung Sejahtera ini merupakan salah satu bentuk perwujudan untuk mencapai kesejahteraan, terutama kesejahteraan masyarakat Kecamatan Kobalima Timur sebagai beranda Negara Kesatuan Republik Indonesia.

Pemenuhan akses standar terhadap pelayanan kesehatan, pendidikan, dan infrastruktur mobilitas warga juga sudah lebih baik. Bidang pendidikan, dimulai dari tingkat Sekolah Dasar, Sekolah Mengah Pertama, dan Sekolah Menengah Atas di Kecamatan Kobalima Timur sudah cukup memadai. Untuk bidang kesehatan juga sudah berjalan dengan baik dengan adanya program dari 
pemerintah daerah. Peningkatan infrasruktur berupa jalan nasional seperti jalan "Sabuk Merah Perbatasan", jalan masuk ke desa-desa (jalan desa), sarana publik pelayanan masyarakat, seperti kantor desa, puskesmas, sekolah, dan saran publik lainnya semakin memudahkan masyarakat Kobalima Timur dalam aktivitas kesehariannya. Jika dibandingkan dengan keadaan masyarakat sebelum adanya peningkatan Pos Lintas Batas Negara (PLBN), keadaan masayarakat Kobalima Timur saat ini boleh dikatakan sudah lebih baik.

Beberapa fakta lintas batas di Pos Lintas Batas Negara Terpadu Motamasin tersebut menjadikan wilayah Kecamatan Kobalima Timur memiliki kemajuan dalam bidang ekonomi. Seiring perkembangan arus lintas batas di PLBN Motamasin, masyarakat di sepanjang jalan menuju Pos Lintas Batas Negara Terpadu Motamasin memanfaatkan peluang ekonomi yang ada dengan membuka toko, kios, dan warung makan. Tidak hanya itu, dengan adanya PLBN Motamasin memiliki pengaruh besar terhadap tingkat pengangguran di Kecamatan Kobalima Timur yakni dengan merekrut tenaga kerja dari 'anak daerah' untuk bekerja di PLBN Motamasin.

Peningkatan perekonomian bagi masyarakat dikawasan perbatasan senada dengan perencanaan pembangunan oleh Kementerian Perencanaan Pembangunan Nasional/Badan Perencanaan Pembangunan Nasional. Bappenas (2017: 142) merekomendasikan pembangunan untuk mencapai sasaran pokok dalam pembangunan wilayah yang meliputi, pertama, meningkatkan pemanfaatan sumber daya alam melalui pengembangan industri pengolahan yang bernilai tambah berorientasi pasar. Kedua, meningkatkan pelayanan sosial yang menyeluruh untuk masyarakat. Ketiga, peningkatan koordinasi dan kerjasama antara pemerintah dan masyarakat. Keempat, adanya reforma agraria untuk memperbaiki akses masyarakat kepada sumbersumber ekonomi, terutama tanah, dan menata ulang ketimpangan pemanfaatan tanah dan sumber-sumber agrarian.

Upaya lain yang dilakukan untuk meningkatkan kesejahteraan masyarakat di kawasan perbatasan khususnya di Kecamatan Kobalima Timur adalah dengan mengembangkan potensi lokal yang diunggulkan. Potensi lokal yang ada di Kecamatan Kobalima Timur meliputi bidang pertanian, peternakan, kehutanan, perikanan. Dengan begitu maka dapat meningkatkan pendapatan masyarakat setempat sehingga kesejahteraan masyarakat bisa tercapai.

Salah satu kegiatan pengembangan ekonomi lokal yang dilaksanakan dan mendapat dukungan penuh dari pemerintah pusat dan pemerintah daerah Kabupaten Malaka adalah adanya kegiatan ekspor bawang merah untuk negara Republik Demokratik Timor Leste. Kegiatan yang dilaksanakan pada Bulan Oktober 2017 tersebut mendapat dukungan dari Kementerian Pertanian Republik Indonesia. Produksi bawang merah di Kabupaten Malaka sebagai bukti keberhasilan dari Program Unggulan Bupati, yakni Revolusi Pertanian Malaka (RPM) tidak hanya untuk konsumsi masyarakat setempat tetapi juga berhasil mengekspor bawang merah sebanyak 30 ton untuk Negara Timor Leste. Pelepasan ekpor bawang merah dilakukan oleh Menteri Pertanian yang diwakili Staf Ahli Mentan Bidang Infrastruktur sekaligus sebagai Penanggung Jawab Program Upaya Khusus Provinsi Nusa Tenggara Timur. Dalam kegiatan tersebut, hadir juga Dirjen Peternakan sebagai perwakilan dari Republik Demokratik Timor Leste (RDTL), Joanita Dakosta Jong.

Proses peningkatan kesejahteraan yang dilakukan bagi masyarakat di kawasan perbatasan tersebut, selaras dengan apa yang disampaikan oleh Dale, dkk., (2010: 217) bahwa dengan meningkatkan vitalitas masyarakat dapat menjadi kebijakan strategis sebagai arah bagi pemerintah dalam proses pembangunan berkelanjutan. Peningkatkan kesejahteraan (meliputi pembangunan infrastruktur, transportasi, energi) di masyarakat harus diperhatikan agar dapat mendorong masyarakat untuk meningkatkan kualitas hidup. Warsilah \& Wardiat (2017: 11) menambahkan bahwa untuk mencapai hal tersebut, penting dilakukan upaya pemberdayaan masyarakat daerah perbatasan dengan cara mengangkat kondisi perekonomian mereka, ketercukupan pangan, dan upaya peningkatan daya saing produksi lokal. Peningkatan perekonomian bagi masyarakat dikawasan perbatasan bertujuan untuk menghindari kehidupan yang menyebabkan masyarakat bergantung kepada negara tetangga.

Sumber daya alam dan sumber daya manusia adalah faktor umum yang sudah melekat dalam kehidupan masyarakat dari generasi ke generasi dan tidak jarang mengandung unsur-unsur yang mendukung pencapaian tujuan pembangunan. 
Dilihat dari kepentingan nasional secara luas, apabila pengelolaan pembangunan pada tingkat masyarakat lokal sudah dapat berjalan dengan baik, hal tersebut dapat mengurangi beban dan tanggung jawab pemerintah pusat dalam melaksanakan pembangunan (Soetomo, 2006: 21).

Demi mewujudkan pencapaian sasaran pokok dalam pengembangan wilayah, pembangunan Indonesia perlu diarahkan untuk mempercepat terwujudnya kesejahteraan dengan meningkatkan pelayanan, pemberdayaan, dan peran serta masyarakat dalam pembangunan. Dengan akselerasi pembangunan terutama pembangunan wilayah Kawasan Timur Indonesia (KTI) yang meliputi, Kalimantan, Sulawesi, Maluku, Nusa Tenggara, dan Papua diharapkan mampu mengurangi kesenjangan antara Kawasan Barat dan Kawasan Timur. Madu, et al., (2010: 204) menyatakan bahwa terwujudnya kesejahteraan sosial ekonomi masyarakat di wilayah perbatasan secara langsung dan tidak langsung tidak hanya mampu meningkatkan rasa nasionalisme, akan tetapi sebagai "benteng" pertahanan terhadap potensi infiltrasi pihak-pihak yang memberi ancaman terhadap Indonesia.

Strategi yang dilaksanakan oleh Badan Pengelola Perbatasan tersebut bertujuan untuk menghadirkan negara hingga ke pelosok tanah air.Melalui pendekatan kesejahteraan (prosperity), Badan Pengelola Perbatasan Propinsi Nusa Tenggara Timur menciptakan kondisi di mana masyarakat perbatasan di Kecamatan Kobalima Timur merasakan adanya peningkatan ekonomi, sosial, budaya dan keamanan di daerah perbatasan. Masyarakat perbatasan perlu diberikan kesempatan untuk dapat menikmati ketersediaan fasilitas dan sarana pendukung lainnya seperti di wilayah nonperbatasan lain. Dalam konteks ini, negara berperan untuk melakukan tindakan untuk menjauhkan masyarakat perbatasan dari kondisi ketertinggalan. Warsilah \& Wardiat (2017: 2) menyatakan sebagian besar kawasan perbatasan di Indonesia merupakan kawasan tertinggal dengan sarana dan prasarana sosial dan ekonomi yang sangat terbatas.

Kehidupan masyarakat yang sejahtera merupakan kondisi ideal yang menjadi dambaan setiap warga negara. Oleh karena itu, upaya pada umumya masalah sosial ditafsirkan sebagai keadaan yang tidak diinginkan oleh masyarakat. Kondisi ini dianggap sebagai masalah yang dapat menimbulkan berbagai penderitaan dan kerugian baik fisik maupun nonfisik (Soetomo, 2010: 1). Mengerucut pada kehidupan masyarakat di perbatasan, masalah sosial tersebut memiliki pengaruh besar terhadap nasionalisme masyarakat di kawasan perbatasan. Nasionalisme bukan sekedar instrumen yang memiliki fungsi sebagai perekat kemajemukan secara eksternal tetapi nasionalisme menegaskan identitas Indonesia yang bersifat plural dalam dimensi kultural (Kusumawardani dan Faturochma, 2004: 63).

Cinta tanah air sering diartikan sebagai nasionalisme. Perasaan cinta tanah air dapat diwujudkan dengan, pertama, menjaga nama baik bangsa; kedua, berjiwa dan berkepribadian, ketiga, bangga betanah air dengan beraneka ragam etnis; keempat, tidak melakukan tindakan yang merugikan bangsa; dan kelima, setia dan taat pada aturan dan norma yang berlaku (Ikhsan, 2017: 113).Pengembangan kawasan perbatasan lebih ditekankan terhadap aspek manusia sebagai entitas yang rentan dalam pemahaman nasionalisme kontemporer. Dalam konteks ini, nasionalisme kontemporer sekarang lebih kepada perlindungan. Peryataan ini cukup kontras dengan peryataan klasik mengenai pemahaman nasionalisme yakni loyalitas warga negara kepada negaranya. Akan tetapi, sekarang ini justru negara yang harus bisa menghadirkan diri untuk memenuhi setiap kepentingan dan melayani kepentingan aspirasi publik (Andriana, 2016: 46).

Apabila dilihat pada konteks nasionalisme kontemporer tersebut, maka dapat dinyatakan bahwa negara melalui peran pemerintah, baik pemerintah daerah maupun pemerintah pusat, harus terlibat secara aktif dalam pengelolaan perbatasan.Dalam mewujudkannya diperlukan kebijakan asimetris untuk mengelola kawasan perbatasan yang meliputi pemenuhan pelayanan publik di kawasan perbatasan.Pemenuhan pelayanan publik di kawasan perbatasan termasuk dalam peningkatan infrastruktur dasar wilayah, sosial, ekonomi, pemerintahan, dan berbagai aspek lain. Pemenuhan pelayanan publik tersebut merupakan tindakan tepat untuk meningkatkan kualitas hidup masyarakat perbatasan serta dapat mewujudkan masyarakat perbatasan yang sejahtera. Pelaksanaan pembangunan dengan memenuhi kebutuhan masyarakat dapat menguatkan nasionalisme dalam konteks kekinian yang lebih riil dan diterima oleh masyarakat sehingga kesetiaan masyarakat pada negara semakin besar. 


\section{SIMPULAN}

Pendekatan kesejahteraan yang dilaksanakan di Kecmatan Kobalima Timuroleh Badan Pengelola Perbatasan Nusa Tenggara Timur merupakan tindakan yang tepat untuk meningkatkan kualitas hidup masyarakat,mewujudkan masyarakat yang sejahtera, dan menguatkan nasionalisme masyarakat perbatasan.Pendekatan kesejahteraan tersebutterdiri daripertama, pembangunan dan

\section{DAFTAR RUJUKAN}

Andriana, N. 2016. Nasionalisme dan Keindonesiaan di Perbatasan. Yogyakarta: Calpulis.

Arifin, S. 2014. Hukum Perbatasan Darat antar Negara. Jakarta: Sinar Grafika.

Bakry, N. M. 2014. Pendidikan kewarganegaraan. Yogyakarta: Pustaka Pelajar.

Bappenas. 2017. Evaluasi Paruh Waktu RPJMN 2015-2019: Kerja Nyata Mewujudkan Indonesia yang Berdaulat, Mandiri dan Berkepribadian. Jakarta: BAPPENAS.

Dale, A., Ling C., \& Newman, L. 2010. Community vitality: the role of community-level resilience adaptation and innovation in sustainable development. Sustainability, 2 (1), 215-231.

Ikhsan, M. A. 2017. Nilai - nilai cinta tanah air dalam perspektif Al-Qur'an. Jurnal Ilmiah Pendidikan Pancasila dan Kewarganegaraan, 2 (2), 108-114

Kingsbury, D. 2003. The political economy of cross-borderrelations the TNI and East Timor. South East Asia Research, 11(3), 269-296

Kusumawardani, A., \& Faturochman. 2004. Nasionalisme. Buletin Psikologi, 12 (2), 61-72.

Lan, T. J. \&Manan, M. A. 2011. Nasionalisme dan Ketahanan Budaya di Indonesia: Sebuah Tantangan. Jakarta: LIPI Press.

Madu, L., Nugraha, A., Loy, N., Fauzan. 2010. Mengelola Perbatasan Indonesia di Dunia Tanpa Batas: Isu, Permasalahan dan Pilihan Kebijakan. Yogyakarta: Graha Ilmu.

Mansyah, A. 2017. Nasionalisme masyarakat Indonesia di perbatasan dan dampaknya terhadap kedaulatan negara (Studi di Kabupaten Sanggau, Kalimantan Barat). Jurnal Prodi Peperangan Asimetris, 3 (3), 17-40. peningkatan infrastruktur di kawasan perbatasan. Kedua, peningkatan kesejateraan masyarakat perbatasan.Strategi yang dilaksanakan oleh Badan Pengelola Perbatasan tersebut mengindikasikan bahwa negara hadir dan memperhatikan masyarakat perbatasan sehingga loyalitas masyarakat terhadap negara semakin besar dan mampumempertahankan eksistensi ke-Indonesiaan di kawasan perbatasan.

Moeldoko. 2014. Kebijakan dan scenario planning pengelolaan kawasan perbatasan di Indonesia 2030: Studi Kasus Perbatasan Darat di Kalimantan. Disertasitidak diterbitkan. Universitas Indonesia Jakarta.

Muta'ali, L., Marwasta, D., \& Christanto, J. 2014. Pengelolaan Wilayah Perbatasan NKRI. Yogyakarta: Gadja Madah University Press.

Nugroho, A. 2016. NilaiBela Negara. (https:// jpp.go.id/infografis/60-indicator-kesadaran. Diakses 5 September 2018).

Pamungkas, C. (2015) Nasionalisme Masyarakat Di Perbatasan Laut: Studi Kasus, Masyarakat Melayu-Karimun. Masyarakat Indonesia. 41 (2), 147-162.

Saiman. (2017).Kepentingan Pemerintah Pusat Dalam Pembangunan Infrastruktur Perbatasan Kalimantan Indonesia-Malaysia Era Presiden Susilo Bambang Yudhoyono.Jurnal Sospol,3 (1), 142-161.

Sugiyono. (2016). Metode Penelitian Kombinasi (Mixed Methods) (8rd ed). Bandung: Penerbit Alfabeta.

Soetomo. (2006). Strategi Pembangunan Masyarakat. Yogyakarta: Pustaka Pelajar

Warsilah, H dan Wardiat, D. (2017). Pembangunan Sosial di Wilayah Perbatasan Kapuas Hulu Kalimantan Barat. Jakarta: Yayasan Pustaka Obor Indonesia.

Wuryandari, G., Pamungkas, C., Noor, F., \& Hadiwinata, B. S. (2009). Keamanan di Perbatasan Indonesia-Timor Leste. Yogyakarta: Pustaka Pelajar.

Yin, R. K. (2011). Qualitative Research from Start to Finish. New York: The Guilford Press. 